\title{
PRIMJENA NAČELA ODRŽIVE MOBILNOSTI NA UNAPRJEĐENJU PROMETNIH UVJETA MANJIH GRADOVA
}

\author{
APPLICATION OF SUSTAINABLE MOBILITY \\ PRINCIPLES ON ENHANCEMENT OF TRAFFIC \\ CONDITIONS IN SMALLER CITIES
}

Aleksandra Deluka-Tibljaš , Sanja Šurdonja*, Dolores Markovićc

\section{Sažetak}

Održiva mobilnost ima za cilj osiguravanje mobilnosti, prvenstveno u urbanim područjima, uz istovremeno racionalno korištenje prostora, okoliša i pozitivan utjecaj na zdravlje i općenito kvalitetu života. U ovome radu se prikazuje primjena ovoga koncepta na primjeru manjeg grada, Grada Otočca. Odabrana je uža zona centra Otočca za koju su analizirani prometno-prostorni pokazatelji te predložena rješenja kojima se uz minimalnu dodatnu izgradnju može postići unaprjeđenje prometnog sustava, što je u radu obrazloženo.

Ključne riječi: održiva mobilnost, prometni sustav, Grad Otočac

\begin{abstract}
Sustainable mobility has a goal to assure mobility, mostly in urban areas, and rationally use space and environment at the same time, not neglecting its impact and positive effects on human health and quality of life. In this paper application of this concept is presented on the example of the City of Otočac. The chosen area was the city center for which all necessary traffic and spatial analyses were done and some possible solutions for enhancing traffic conditions with minimal investments were proposed and evaluated.
\end{abstract}

Key words: sustainable mobility, traffic system, City of Otočac

${ }^{*}$ Građevinski fakultet Sveučilišta u Rijeci, Radmile Matejčić 3, Rijeka

E-mail: \{aleksandra.deluka, sanja.surdonja\}@uniri.hr, dolores.markovic@student.uniri.hr 


\section{Uvod}

Prometni sustav jedan je od ključnih elemenata funkcioniranja i razvoja gradova i njime se uobičajeno nastoji povezati područje grada kako bi se stanovništvu osigurala mobilnost (kretanje) u svrhu zadovoljavanja određenih potreba. Prekomjerni porast motorizacije i njezin negativni utjecaj na kvalitetu života u gradovima doveo je posljednjih desetljeća do potrebe definiranje novog koncepta razvoja grada i prometa pa se danas sve više govori o osiguravanju „pristupačnosti“ umjesto „mobilnosti“ [1]. Osiguravanje pristupačnosti podrazumijeva usko povezivanje prostornog i prometnog planiranja kako bi se lociranjem određenih sadržaja smanjila potreba za mobilnošću, odnosno, kako bi stanovnici što veći dio svojih dnevnih putovanja (škola, trgovina, različite usluge) mogli obaviti na pješačko-biciklističkoj udaljenost od mjesta stanovanja. Istovremeno, rješenje za mobilnost nije više samo izgradnja nove infrastrukture već to postaje efikasnije korištenje postojeće infrastrukture kroz učinkovitije upravljanje prijevoznom potražnjom. Pritom se prijevozna potražnja usmjerava na one prometne sustave koji imaju povoljniji utjecaj na okolišs, zdravlje i općenito kvalitetu života u gradovima (javni prijevoz, nemotorizirani vidovi prometa te druga sustavna rješenja za javni i individualni prijevoz). Sve navedeno dio je šireg koncepta osiguravanja održive mobilnosti u urbanim područjima koji za cilj ima doprinos prostornoj, energetskoj, ekološkoj i ekonomskoj racionalizaciji [2].

Održiva mobilnost, kao koncept, svoju operacionalizaciju doživljava kroz na razini EU formalno uspostavljene planove održive urbane mobilnosti, engl. sustainable mobility plan (skraćenica SUMP). Prema definiciji, plan održive urbane mobilnosti (u daljnjem tekstu POUM) u gradovima definira se kao strateški plan koji se nadovezuje na postojeću praksu u planiranju mobilnosti i uzima u obzir integracijske, participacijske i evaluacijske principe kako bi zadovoljio potrebe stanovnika gradova za mobilnošću sada i u budućnosti te osigurao bolju kvalitetu života u gradovima i njihovoj okolini [2]. Prvenstveno se planovi ove vrste izrađuju za veće gradove kod kojih koncentracija stanovništva i njihove dnevne migracije značajno utječu na opću kvalitetu života.

U ovome radu cilj je analizirati kako se načela održive mobilnosti mogu primijeniti u manjem gradu u kojem nema izraženih posljedica prekapacitiranog prometnog sustava (čekanja, zagušenja, buka...). $\mathrm{Na}$ primjeru primjene načela održive mobilnosti u gradu Otočcu nastoji se, na osnovu dostupnih podataka i analize prostornih i prometnih uvjeta u odabranoj zoni Otočca, zaključiti što primjena ovog koncepta može značiti te koliko i kako doprinijeti unaprjeđenju kvalitete života. 


\section{Plan održive mobilnosti}

\subsection{Općenito o planovima održive mobilnosti}

Izrada i realizacija POUM-a u hrvatskim gradovima u skladu je s prometnom politikom Europske Unije koja je 2009. godine objavila akcijski plan urbane mobilnosti. Usvojena je i Europska strategija 2020 po kojoj gradovi bez obzira na broj stanovnika imaju ključnu ulogu u izradi i realizaciji POUM-a jer je gradski promet najznačajniji potrošač energije i uzrok emisije stakleničkih plinova [2]. POUM predstavlja inovativni način planiranja gradskog prometa koji na održivi način zadovoljava ponajprije potrebe ljudi i stavlja naglasak na uključivanje i sudjelovanje građana i ostalih sudionika u prometnom planiranju. POUM planira usklađivanje odluka u sektorima prometa, prostornog planiranja, gospodarskog razvoja, društvene djelatnosti, sektoru zdravstva, energetike, sigurnosti itd. Planovi održive mobilnosti pored uključivanja svih resursa moraju uključivati sve oblike i načine prijevoza u gradu, javni i privatni, putnički i robni, motorizirani i nemotorizirani. Veliku ulogu u Planovima mobilnosti ima parkiranje jer uređenje mjesta i pravila upravljanja parkirnim mjestima i ponuda parkirnih mjesta ima veliki utjecaj na korištenje osobnog ili javnog prijevoza [3].

Cilj planova održive mobilnosti u gradovima je stvaranje održivog prometnog sustava pomoću: osiguravanja dostupnosti poslova i usluga svima, poboljšanja sigurnosti i zaštite, smanjenja zagađenja, emisije stakleničkih plinova i potrošnje energije, povećanja učinkovitosti i ekonomičnosti u transportu osoba i roba i povećanja atraktivnosti i kvalitete gradskog okoliša [4].

Osnovne karakteristike POUM-a su sljedeće:

- jasna vizija, svrha i mjerljivi ciljevi

- održivost koja će uravnotežiti ekonomski razvoj, društvenu pravednost i kvalitetu okoliša

- integrirani pristup - koji uzima u obzir praksu i politike različitih sektora i razina uprave

- revizija transportnih troškova i koristi - uzimajući u obzir ukupne društvene troškove i koristi

- participacijski pristup - koji uključuje građane i sudionike od početka do kraja procesa planiranja [2].

Regulacija i organizacija prometa ovisi o postojećem stanju u urbanoj sredini. Prema kriterijima POUM-a moguće su različite varijante i rješenja. Prva varijanta je uobičajeno ona bez većih građevinskih zahvata i bez većih 
financijskih ulaganja, a temelji se na postojećoj infrastrukturi i već planiranim prometnim projektima. Moguće su i puno složenije varijante koje uključuju izradu novih projekata i izgradnju nove prometne infrastrukture.

\subsection{Plan održive mobilnosti za Otočac}

Grad Otočac svoj budući razvoj temelji na razvoju turizma i prerađivačkih industrija. U Strategiji Grada Otočca, kao jedan od tri glavna cilja za razdoblje 2014.-2018. [5] navodi se "održivo upravljanje prirodnim resursima i zaštita okoliša $s$ naglaskom na racionalno gospodarenje prostorom", dok se unutar ovoga cilja strategije kao mjera ističe "poticanje ispravnog odabira energenata, sirovina, procesa, transportnih i prometnih sredstava i primjena suvremenih metoda kako bi se smanjio utjecaj na zrak, tlo i vode."

Primjena načela održive mobilnosti u Otočcu ne garantira ostvarenje svih potencijalnih ciljeva održive mobilnosti, ali je određenim manjim intervencijama u prometnom sustavu grada moguće ostvariti unaprjeđenje sustava koje će doprinijeti kvaliteti prometne usluge i kvaliteti života građana i posjetitelja Otočca te ujedno doprinijeti zacrtanim ciljevima razvoja grada povezanim sa prometnim sustavom, turizmom i očuvanjem okoliša.

U ovome radu je kao područje obuhvata definirano uže područje centra Grada Otočca gdje se, procijenjeno je, zbog koncentracije stanovništva i aktivnosti, mogu postići i najveći efekti ovoga načina planiranja.

Izrada prijedloga unaprjeđenja prometnih uvjeta u odabranoj zoni kao prvu fazu pretpostavlja prikupljanje podataka o postojećem prometnom sustavu, odnosno bitne pokazatelje za sve postojeće vidove prometa kao i analizu prostora kroz analizu namjene površine te općenito kretanja i navika stanovništva. Osim šireg prostorno-prometnog položaja i namjene površine u zoni obuhvata, analizirani su uvjeti odvijanja pješačkog $i$ biciklističkog prometa, parkiranje, prometna opterećenja i kapaciteti postojećih raskrižja kao i prometno-sigurnosni uvjeti na istima te pristupačnost infrastrukture za sve kategorije stanovnika.

S obzirom na dostupnost podataka o postojećem stanju u prometu definirani su konkretni ciljevi plana održive mobilnosti kao i mjerljivi pokazatelji istog, Tablica 1. 
Tablica 1. Ciljevi plana održive mobilnosti te načini mjerenja ciljeva

\begin{tabular}{|l|l|}
\hline Cilj & Način mjerenja postignutog cilja \\
\hline $\begin{array}{l}\text { Unaprjeđenje uvjeta za biciklistički } \\
\text { promet }\end{array}$ & $\begin{array}{l}\text { Duljina biciklističkih putova odvojenih od } \\
\text { motornog prometa }\end{array}$ \\
\hline Unaprjeđenje pješačkog prometa & $\begin{array}{l}\text { Duljina novih ili proširenih pješačkih } \\
\text { putova }\end{array}$ \\
\hline $\begin{array}{l}\text { Uklanjanje dužuličnih parkirnih } \\
\text { mjesta (sa ciljem osiguravanje bolje } \\
\text { preglednosti na raskrižjima) }\end{array}$ & $\begin{array}{l}\text { Broj dužuličnih parkirnih mjesta koja su } \\
\text { zamijenjena parkirnim mjestima na } \\
\text { izvanuličnim parkiralištima }\end{array}$ \\
\hline $\begin{array}{l}\text { Osiguravanje kretanja svim } \\
\text { kategorijama stanovništva }\end{array}$ & $\begin{array}{l}\text { Broj pješačkih prijelaza prilagođenih } \\
\text { kretanju osoba slabije pokretljivosti }\end{array}$ \\
\hline
\end{tabular}

\section{Analiza postojećih prometnih uvjeta u području obuhvata}

\subsection{Opći podaci o području obuhvata}

Grad Otočac smješten je u Ličko-senjskoj županiji, u zapadnom dijelu Gackoga polja na 459 m.n.m. Područje Grada Otočca površine je 565,3 km². Dimenzije prostora Grada pružaju se prosječnom dužinom u smjeru istok zapad od 20 - 32 kilometra, te prosječnom širinom u smjeru sjever - jug 23 - 32 kilometra [6].

Grad Otočac ima izuzetno dobar prometni položaj jer je smješten na trasi državne ceste D-50 (Ulica Kralja Zvonimira) koja povezuje središnju Hrvatsku s obalnim područjem. Izgradnjom autoceste A1 Zagreb-Split, grad je ostvario dobru prometnu povezanost s većim gradskim središtima. Područjem Grada Otočca prema podacima iz "Odluke o razvrstavanju javnih cesta" (NN br. 66/2013) prolazi 248,14 km javnih (razvrstanih) cesta, od toga 33,83 km autocesta (A1), 39,25 km državne ceste (D50 i D52), 86,10 km županijske ceste (ŽC) i 88,96 km lokalnih cesta (LC). [7]

Grad Otočac sastoji se od 22 naselja. Prema popisu stanovništva iz 2011. godine na području grada živi 9.778 stanovnika, (od čega u samom Otočcu 4.240). Gustoća naseljenosti u Otočcu je 17 stanovnika na $\mathrm{km}^{2}$. Prema navedenom popisu iz 2011. godine u Gradu je živjelo 19\% stanovnika dobne skupine od 0-19 godina, 51\% stanovnika u dobnoj skupini od 20-59 godina i čak 30\% starosna grupa preko 60 godina, što je iznad kritične granice udjela starog stanovništva od 12\% [6]. Najbrojnija je dobna skupina od 2059 godina pa se sa sigurnošću može pretpostaviti da su pripadnici te skupine ujedno i aktivni sudionici u prometu kao vozači motornih vozila, dok drugu polovicu stanovništva čine ugrožene skupine: djeca i staro stanovništvo. 
Područje obuhvata u ovome radu je samo središte grada Otočca; kroz cijelu zonu obuhvata proteže se glavna ulica, Ulica kralja Zvonimira (Slika 1). U zoni su locirani svi bitni gradski sadržaji trgovačkog, turističkog, administrativnog, obrazovnog i sportsko-rekreativnog karaktera, stambena namjena dominira u Ulici Bartola Kašića, od križanja sa Ulicom kralja Zvonimira do križanja sa Ulicom Stjepana Radića.

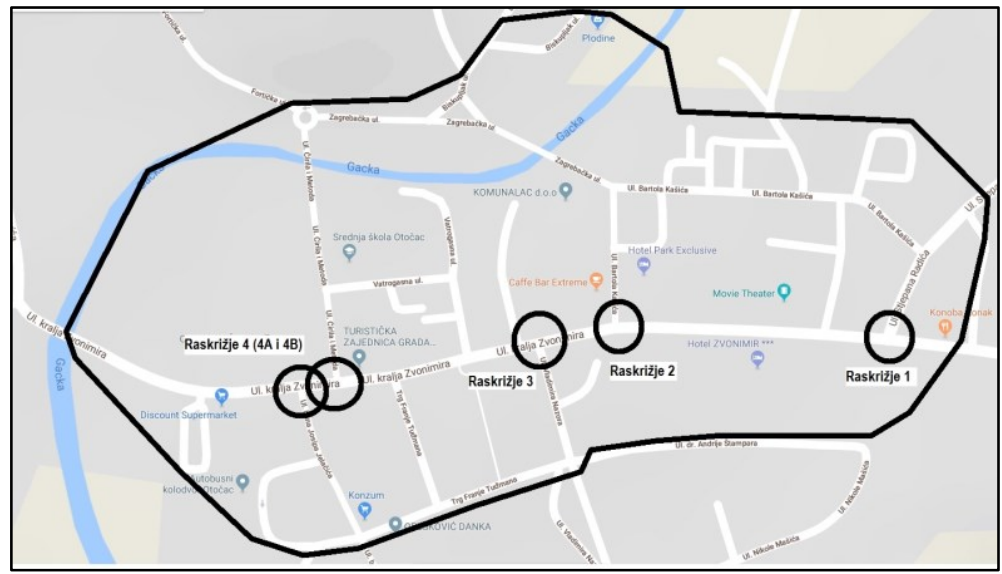

Slika 1. Zona obuhvata sa oznakama analiziranih raskrižja

\subsection{Analiza postojećih prometnih uvjeta}

U zoni obuhvata detaljno je analizirana cestovna mreža, značajnija raskrižja u centru (4 raskrižja), parkiranje (ulično i vanulično) te pješačke i biciklističke staze. Detaljna analiza i dodatni grafički prilozi dostupni su u diplomskome radu na kojem se ovaj rad temelji [8].

\subsubsection{Cestovna mreža i raskrižja u zoni obuhvata}

Prema kategorizaciji Hrvatskih cesta, kroz zonu prolazi državna cesta DC 50 (Ulica kralja Zvonimira), županijska cesta ŽC 5128 (Ulicu Stjepana Radića) i ŽC 5143 (Ulicu bana Josipa Jelačića). Ostale ceste su lokalnog i nerazvrstanog karaktera. U ovom su radu analizirana četiri raskrižja na državnoj cesti D50 (Slika 1):

1. Raskrižje Ulice Stjepana Radića i Ulice kralja Zvonimira (raskrižje 1)

2. Raskrižje Ulice Bartola Kašića i Ulice kralja Zvonimira (raskrižje 2)

3. Raskrižje Ulice Vladimira Nazora i Ulice kralja Zvonimira (raskrižje 3)

4. Raskrižje Ulica Ćirila i Metoda - Ulica kralja Zvonimira - Ulica bana Josipa Jelačića (raskrižje 4A i 4B). 
Za svako raskrižje provedena je analiza postojećeg stanja koja je obuhvaćala brojanje prometa na raskrižju u vršnom satu, mjerenje trajanja ciklusa semafora (na raskrižjima 1 i 4B), analizu preglednosti na raskrižju, analizu broja potencijalnih kolizionih točaka te analizu razine uslužnosti na raskrižju.

Brojanje prometa na svakom raskrižju provedeno je u jutarnjem i popodnevnom vršnom satu, a kao mjerodavni usvojen je jutarnji vršni sat (7:00 -8:00). Vozila su podijeljena u 4 kategorije: osobna vozila, teretna vozila, autobusi te motocikli. U Tablici 2 prikazano je prometno opterećenje izraženo putničkim automobilskim jedinicama (PAJ), a za homogenizaciju su korišteni slijedeći koeficijenti: 1 za osobna vozila, 1.5 za autobuse i teretna vozila te 0.5 za motocikle. Na oba semaforizirana raskrižja (1 i 4) mjerenjem je utvrđen ciklus semafora u trajanju $60 \mathrm{~s}$ u 2 faze. Analiza preglednosti provedena je prema Američkim smjernicama za projektiranje cesta, tzv. Greenbook, jer iste uključuju veći broj parametara te je proračunata duljina preglednosti preciznije određena nego postojećom hrvatskom normom [9]. Na situacionim nacrtima, na temelju definiranih dozvoljenih smjerova kretanja te broja prometnih traka, određene su kolizione točke. Količina vozila i ciklusi semafora (u slučaju semaforiziranih raskrižja) ulazni su parametri na temelju kojih je određena razina uslužnosti raskrižja pomoću softvera SIDRA INTERSECTION 6.1. U Tablici 2 prikazani su rezultati analize postojećeg stanja za sva raskrižja.

Tablica 2. Rezultati analize postojećeg stanja raskrižja

\begin{tabular}{|c|c|c|c|c|c|}
\hline Raskrižje & Privoz & $\begin{array}{l}\text { Prometno } \\
\text { opterećenje } \\
{[\mathrm{PAJ}]}\end{array}$ & $\begin{array}{l}\text { Kolizione } \\
\text { točke }\end{array}$ & $\begin{array}{l}\text { Preglednost } \\
\text { na raskrižju }\end{array}$ & $\begin{array}{l}\text { Razina } \\
\text { uslužnosti }\end{array}$ \\
\hline \multirow{3}{*}{ Raskrižje 1} & 1 & 273 & \multirow{3}{*}{$\begin{array}{l}15 \text { voz-voz } \\
7 \text { voz-pješ }\end{array}$} & \multirow{3}{*}{ Zadovoljena } & C \\
\hline & 2 & 451,5 & & & $A$ \\
\hline & 3 & 468 & & & $B / A$ \\
\hline \multirow{3}{*}{ Raskrižje 2} & 1 & 262,5 & \multirow{3}{*}{$\begin{array}{l}9 \text { voz-voz } \\
2 \text { voz-pješ }\end{array}$} & \multirow{3}{*}{$\begin{array}{l}\text { Na sporednom } \\
\text { ne zadovoljava }\end{array}$} & $\mathrm{C}$ \\
\hline & 2 & 574,5 & & & $A$ \\
\hline & 3 & 458,5 & & & $A$ \\
\hline \multirow{3}{*}{ Raskrižje 3} & 1 & 226,5 & \multirow{3}{*}{$\begin{array}{l}9 \text { voz-voz } \\
4 \text { voz-pješ }\end{array}$} & \multirow[t]{3}{*}{ Zadovoljena } & $B$ \\
\hline & 2 & 376 & & & A \\
\hline & 3 & 420,5 & & & $A$ \\
\hline \multirow{3}{*}{ Raskrižje 4A } & 1 & 522 & \multirow{3}{*}{$\begin{array}{l}6 \text { voz-voz } \\
2 \text { voz-pješ }\end{array}$} & \multirow[t]{3}{*}{ Zadovoljena } & A \\
\hline & 2 & 169,5 & & & A \\
\hline & 3 & 432,5 & & & $A$ \\
\hline \multirow{3}{*}{ Raskrižje 4B } & 1 & 392 & \multirow{3}{*}{$\begin{array}{l}8 \text { voz-voz } \\
5 \text { voz-pješ }\end{array}$} & \multirow[t]{3}{*}{ Zadovoljena } & $B$ \\
\hline & 2 & 215 & & & $B$ \\
\hline & 3 & 154 & & & C \\
\hline
\end{tabular}


Raskrižja 1, 2 i 3 su trokraka pravilna raskrižja, od čega su raskrižja 2 i 3 nesemaforizirana. Raskrižje 4 je netipično, dijelom semaforizirano četverokrako raskrižje, koje se za potrebe analize razine uslužnosti razmatralo kao dva trokraka raskrižja.

Rezultati analize postojećeg stanja na navedenim raskrižjima pokazuju da su raskrižja slabije prometno opterećena, što je rezultiralo vrlo dobrom razinom uslužnosti na gotovo svim privozima raskrižja (najlošija je razina C, samo u 3 slučaja).

Preglednost je zadovoljena na svim osim na sporednom privozu raskrižja 2, gdje je zbog parkiranih vozila na glavnom smjeru onemogućena dobra preglednost vozilima iz sporednog smjera.

\subsubsection{Parkiranje u zoni obuhvata}

U zoni obuhvata ima ukupno 654 označenih parkirnih mjesta. Najveći broj nalazi se u Ulici kralja Zvonimira u kojoj su označena 242 parkirna mjesta od kojih je veći dio (cca 60\%) ulično parkiranje. Osim za osobne automobile, izgrađena su tri parkirna mjesta za autobuse. Parkirna mjesta u ovoj ulici označena su i u neposrednoj blizini pješačkih prijelaza (na nekim mjestima ta udaljenost iznosi samo $30 \mathrm{~cm}$ ), što znatno utječe na smanjenje preglednosti prometa i predstavlja opasnost za pješake koji prelaze kolnik na označenim prijelazima. U zoni postoje dodatna izvanulična parkirališta sa cca 230 parkirnih mjesta. Parkiranje se ne naplaćuje, a uočeno je da se nepropisano parkiranje tolerira.

\subsubsection{Pješačke i biciklističke staze u zoni obuhvata}

Pješački promet u zoni obuhvata odvija se uređenim nogostupima. Duž Ulice Kralja Zvonimira isti su obostrani i odgovarajuće širine na cijeloj dužini (preko 4,0 m). Od kolnika su najvećim dijelom odvojeni zelenim površinama na kojima se nalazi drvored te parkirnim mjestima, što pridonosi većoj sigurnosti pješaka. Budući da su nogostupi izgrađeni i u ostalim ulicama koje su povezane s Ulicom kralja Zvonimira, pješacima je omogućena dobra povezanost s različitim sadržajima unutar zone.

U ostalim ulicama u promatranoj zoni (Vatrogasna ulica, Ulica Ćirila i Metoda) nogostupi su izgrađeni i uređeni samo djelomično i na nekim mjestima su neodgovarajuće širine (do 1,35 m).

U Zagrebačkoj ulici, nogostupi su obostrani i u većem dijelu neodgovarajuće širine. Najuža točka nalazi se na dijelu mosta preko rijeke Gacke, gdje iznosi svega $80 \mathrm{~cm}$. I na mjestima na kojima su nogostupi odgovarajuće širine, zbog nepropisnog parkiranja vozila, ugrožena je sigurnost pješaka koji za kretanje koriste kolnik. U ulici su obilježena tri 
pješačka prijelaza i to na kružnom toku, u blizini supermarketa te na križanju s Ulicom Bartola Kašića.

\subsubsection{Zaključno o postojećim prometnim uvjetima}

$\mathrm{Na}$ temelju provedene analize sadašnjeg stanja koja je obuhvatila analizu svih vidova prometa unutar zone obuhvata te analizu prometnosigurnosnih uvjeta odvijanja prometa na raskrižjima može se zaključiti da su, s obzirom na manji intenzitet te izgrađene i uređene nogostupe, uvjeti odvijanja prometa u centru Otočca relativno zadovoljavajući, a u nastavku se navode i uočeni elementi kod kojih bi manjim ulaganjima ili prenamjenama prometnih površina bilo moguće unaprijediti uvjete odvijanja prometa.

Glavni uočeni prometni problem su:

- djelomično preuski nogostupi i nogostupi neprilagođeni invalidnim osobama,

- nepropisno parkiranje u pojedinim dijelovima zone,

- nedostatak parkirnih mjesta,

- pješački prijelazi neprilagođeni invalidnim osobama,

- nepostojanje javnog prijevoza putnika (niti infrastrukture za sigurno odvijanje istog, autobusnih stajališta),

- nije osigurana zaustavna preglednost na raskrižju 2 (križanje ulica Bartola Kašića i Ulice kralja Zvonimira).

Nakon provedene analize pješačkih putova u zoni obuhvata može se zaključiti da izgrađeni nogostupi u gotovo svim ulicama omogućavaju pješacima sigurno kretanja gradskim ulicama i pristup svim sadržajima, kako u samom centru grada, tako i šire. Izuzetak je Ulica Ćirila i Metoda u kojoj nogostup nije u potpunosti izgrađen, a u većom dijelu je neodgovarajuće širine. U zoni obuhvata obilježen je ukupno 31 pješački prijelaz na kojima je omogućeno sigurno kretanje pješaka. Isti su odgovarajuće širine, a nekolicinu (7 pješačkih prijelaza) bi trebalo prilagoditi kako bi se invalidnim osobama omogućilo nesmetano prelaženje gradskih ulica i brži dolazak do željenog cilja.

U zoni obuhvata je primijećen nedostatak parkirnih mjesta koji je najizraženiji u Ulici Bartola Kašića. Problem nepropisnog parkiranja uočen je i u Zagrebačkoj ulici. Navedeni problemi mogli bi se riješiti uređenjem novih parkirnih mjesta na prilazima stambenih zgrada.

Što se tiče kapaciteta raskrižja i razine uslužnosti, vidljivo je da je prosječna razina uslužnosti na svim raskrižjima zadovoljavajuća. Nešto lošija razina uslužnosti (razina $\mathrm{C}$ ) uočava se na privozima sa sporednih 
ulica, uglavnom zbog lijevih skretanja. Preglednost kod svih analiziranih raskrižja je zadovoljavajuća osim kod raskrižja 2, i to kod lijevih i desnih skretača iz sporedne ulice, Ulice Bartola Kašića.

\section{Prijedlog za unaprjeđenje prometnih uvjeta u gradu Otočcu na principima održive mobilnosti}

U cilju poboljšanja prometnih uvjeta u zoni obuhvata predviđena je (Slika 2) [8]:

- izgradnja biciklističko-pješačkih staza u Ulici kralja Zvonimira i prenamjena ostalih ulica u ceste za mješoviti promet,

- izgradnja autobusnih stajališta u Ulici kralja Zvonimira,

- izgradnja parkirališta u Zagrebačkoj ulici,

- rekonstrukcija križanja Zagrebačke ulice i Ulice Bartola Kašića,

- rekonstrukcija dijela Ulice Ćirila i Metoda i Vatrogasne ulice.

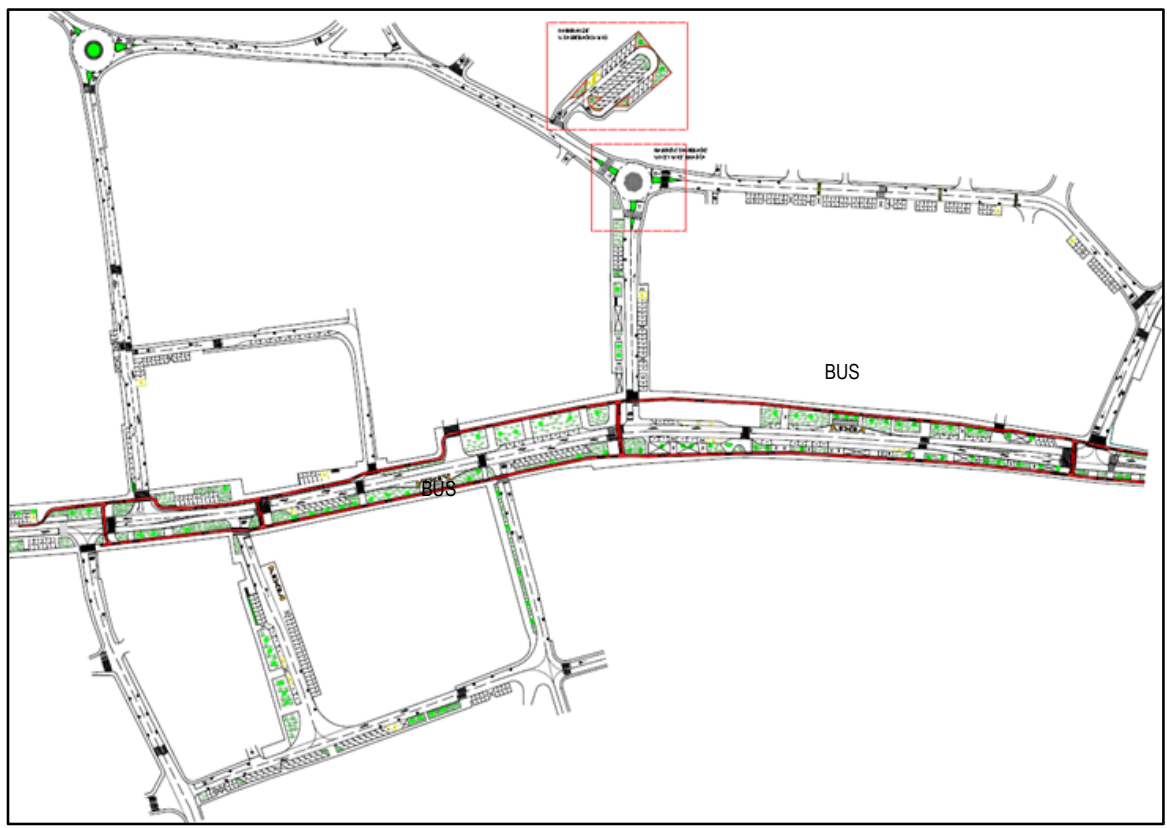

Slika 2. Zona obuhvata s prikazom novog rješenja prometne infrastrukture[8]

Izgradnjom biciklističko-pješačkih staza i prenamjenom ulica u ceste za mješoviti promet poboljšali bi se uvjeti odvijanja biciklističkog prometa $u$ zoni obuhvata i time potaklo stanovnike na učestalije korištenje bicikala u 
prometu. Uvođenje javnog prijevoza i izgradnja autobusnih stajališta omogućili bi stanovništvu lakši i jednostavniji dolazak do svih sadržaja u zoni obuhvata te bi utjecalo na smanjenje motornog prometa u centru grada, a time i na smanjenje ispušnih plinova. Izgradnjom parkirališta povećali bi se kapaciteti parkirnih mjesta i vozačima bi se omogućilo parkiranje u neposrednoj blizini centra grada, što je posebno značajno za ljetne mjesece kada je promet pojačan, a sadašnji kapaciteti parkirnih mjesta nisu dostatni. Izgradnja kružnog raskrižja povećala bi sigurnost prometa na križanju kao i njegovu propusnost te bi utjecala na smirenje prometa.

Osim navedenih rješenja koja su detaljnije elaborirana u nastavku, predlaže se i prilagođavanje svih pješačkih prijelaza osobama sa invaliditetom.

\subsection{Biciklističko-pješačke staze u Ulici kralja Zvonimira i prenamjena ostalih ulica u ceste za mješoviti promet}

Kako bi se stvorili bolji uvjeti za odvijanje biciklističkog prometa u zoni obuhvata, planirana je izgradnja biciklističko-pješačkih staza u Ulici kralja Zvonimira i prenamjena ostalih cesta u ceste za mješoviti promet. Načela planiranja te elemente za projektiranje, izgradnju i održavanje biciklističke infrastrukture propisuje Pravilnik o biciklističkoj infrastrukturi (NN 28/2016). Istraživanja pokazuju da su sigurni biciklistički putovi najvažniji preduvjet za razvoj ovog vida prometa te se može očekivati da bi osiguravanje primjerene biciklističke infrastrukture (uz putove to je još i parkiranje za bicikle) sigurno doprinijelo povećanju udjela biciklističkog prometa u prometu Grada Otočca.

Biciklističko-pješačka staza je prometna površina namijenjena za kretanje biciklista i pješaka, izgrađena odvojeno od kolnika i označena odgovarajućom signalizacijom [10]. Biciklisti i pješaci u pravilu ne smetaju jedni drugima budući da se kreću sličnom brzinom, a biciklisti vožnju uglavnom prilagođavaju pješacima. Opasnost sudara pješaka i biciklista je neznatna u usporedbi s mogućim sudarima prilikom miješanja biciklista ili pješaka s motornim vozilima. Prednost ovakvog rješenja za bicikliste su kraći put i lakši pristup odredištima.

Analizirajući postojeću prometnu infrastrukturu u Ulici Kralja Zvonimira, na postojećim nogostupima je planirana izgradnja jednosmjernih biciklističko-pješačkih staza s obje strane ulice. Staza za bicikliste planirana je u širini od 1,5 m i od kolnika je odvojena zelenilom, osim na jednom manjem dijelu gdje je od prometnice odvojena $0,5 \mathrm{~m}$ zbog sigurnosti biciklista. 
Prilikom izgradnje biciklističke infrastrukture posebnu pozornost treba posvetiti načinu vođenja biciklističkog prometa preko raskrižja budući da se u raskrižju odvijaju složenije prometne situacije koje direktno ugrožavaju sigurnost sudionika u prometu. Prilikom vođenja biciklista unutar raskrižja potrebno je osigurati da isti budu pravovremeno uočljivi iz svih prilaza svim sudionicima $\mathrm{u}$ prometu. Također treba osigurati preglednost između biciklista i drugih sudionika u prometu.

Prijelaz biciklističke staze preko raskrižja označen je uz pješački prijelaz na strani bliže centru raskrižja kvadratićima bijele boje dimenzije $0,5 \mathrm{~m}$. Vođenje biciklističke staze preko privoza sporedne ceste predviđeno je izravno (Slika 3).

U ostalim ulicama u zoni obuhvata nogostupi nisu dovoljno široki da se dio širine odvoji za biciklističku stazu, a konfiguracija terena ne omogućuje njihovo proširenje i izgradnju biciklističko-pješačkih staza pa su iste prenamijenjene u ceste za mješoviti promet.

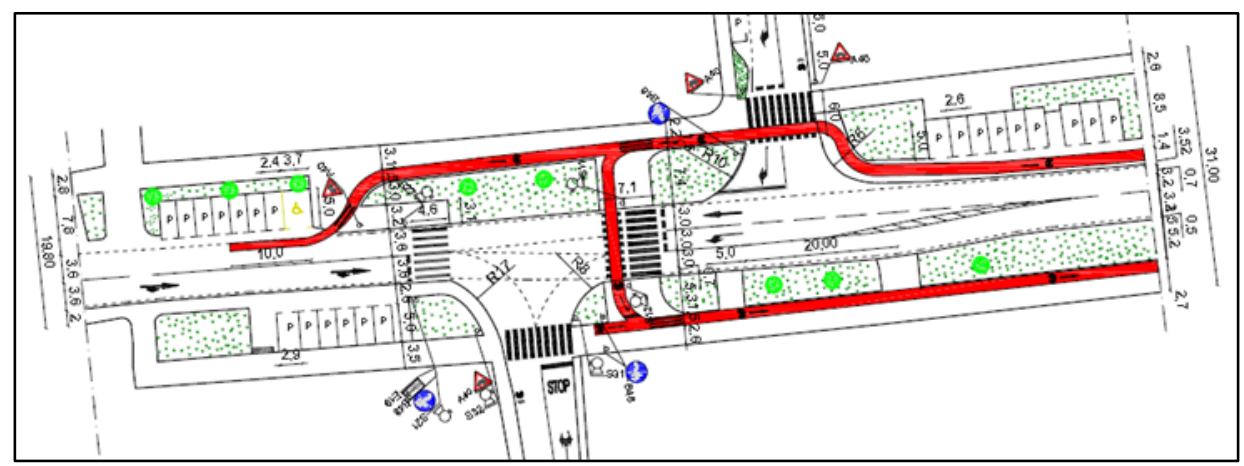

Slika 3. Vođenje biciklističke staze u zoni raskrižja [8]

Cesta za mješoviti promet je prometna površina po kojoj se zajednički odvija biciklistički i motorni promet. Na kolnicima se, u skladu s Pravilnikom o biciklističkoj infrastrukturi, postavljaju prometni znakovi i oznake kojima se vozači motornih vozila upozoravaju na pojavu biciklista u prometu.

Ukupno je navedenim rješenjima predloženo da se izvede približno 950 $m$ jednosmjernih biciklističkih staza te obilježi 9 prijelaza biciklističke staze preko kolnika, od čega 4 na glavnom prometnom smjeru u Ulici Kralja Zvonimira. Sve ostale ulice u zoni primjereno su obilježene kao ceste za mješoviti promet. Način obilježavanja prikazan je na Slici 3. 


\subsection{Autobusna stajališta u Ulici kralja Zvonimira}

Javni gradski prijevoz omogućio bi stanovnicima grada, a naročito mlađoj i starijoj populaciji, lakšu pristupačnost gradskim sadržajima te bi utjecao na smanjenje motornog prometa u samom centru grada, a time i na smanjenje emisije štetnih plinova. Unutar zone obuhvata planirana je izgradnja dvaju autobusnih postaja na državnoj cesti DC 50 u kojoj ograničenje brzine iznosi $50 \mathrm{~km} / \mathrm{h}$. Slika 2 prikazuje položaj autobusnih postaja. Analiza pješačke dostupnosti od lokacije ovih postaja opravdava njihov položaj jer je gravitacionom zonom 5-minutnog pješačenja (cca $400 \mathrm{~m}$ ) obuhvaćena cijela Zvonimirova ulica te priključne ceste prikazane na Slici 2. U radu nisu analizirane moguće autobusne linije.

\subsection{Rekonstrukcija križanja Zagrebačke ulice i Ulice Bartola Kašića}

Križanje Zagrebačke ulice i Ulice Bartola Kašića je trokrako nesemaforizirano raskrižje na kojemu se Ulica Bartola Kašića pruža jednim dijelom u smjeru istoka, a drugim u smjeru juga. Krakovi ulice odvajaju se gotovo pod pravim kutom. Vozači iz smjera Zagrebačke ulice imaju znak obaveznog zaustavljanja, tako da se moraju zaustaviti prije ulaska u raskrižje bez obzira na to odvija li se promet u Ulici Bartola Kašića ili ne.

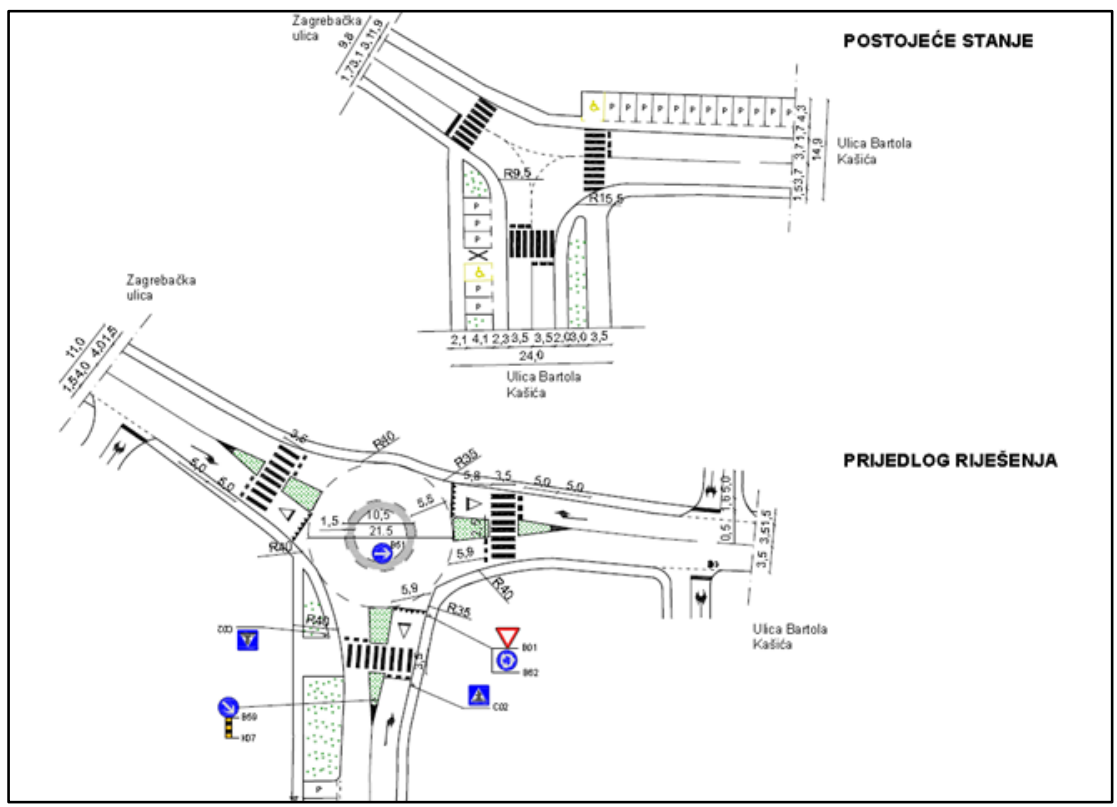

Slika 4. Prikaz postojećeg i predloženog (kružnog) raskrižja na križanju Zagrebačke ulice i Ulice Bartola Kašića [8] 
Kako bi se postigao sigurniji (manji broj kolizionih točaka) i brži prolazak vozila kroz raskrižje (nije potrebno zaustavljanje) te smanjila brzina kretanja vozila u Ulici Bartola Kašića, predviđena je izgradnja kružnog raskrižja (Slika 4).

Predviđeno je jednotračno kružno raskrižje s vanjskim promjerom od $21,5 \mathrm{~m}$. Kružni prometni trak je širine $5,5 \mathrm{~m}$, a središnji razdjelni otok je promjera $10,5 \mathrm{~m}$ s prijelaznim prstenom širine $1,5 \mathrm{~m}$. Središnji otok ima prevozni dio kako bi se teretnim motornim vozilima omogućio prolazak kroz kružni tok. Na svakom od privoza su predviđeni razdjelni otoci. Biciklistički promet unutar kružnog raskrižja odvija se identično motornom prometu budući da se radi o križanju cesta za mješoviti promet. Postojeće i predloženo kružno raskrižje prikazani su na Slici 4.

\subsection{Parkiranje u zoni}

Predloženim rješenjem nastojao se revidirati broj dužuličnih parkirnih mjesta u glavnoj ulici, Ulici Kralja Zvonimira, čime se postigla bolja preglednost na određenim raskrižjima (ukupno $8 \mathrm{PM}$ ) te osigurao prostor za formiranje autobusnih postaja (ukupno $21 \mathrm{PM}$ ). Zbog implementacije kružnog raskrižja, na križanju Ulica Bartola Kašića i Zagrebačke ulice također je uklonjen dio parkirnih mjesta (Slika 4).

Uklonjena parkirna mjesta su nadomještena uređenjem izvanuličnog parkirališta s 33 PM (Slika 5) u Zagrebačkoj ulici, a uređena su i dužulična parkirna mjesta u Ulicama Ćirila i Metoda te Vatrogasnoj ulici, čime je ukupni broj parkirnih mjesta u zoni ostao isti, ali je sada veći dio objedinjen na posebnoj površini.

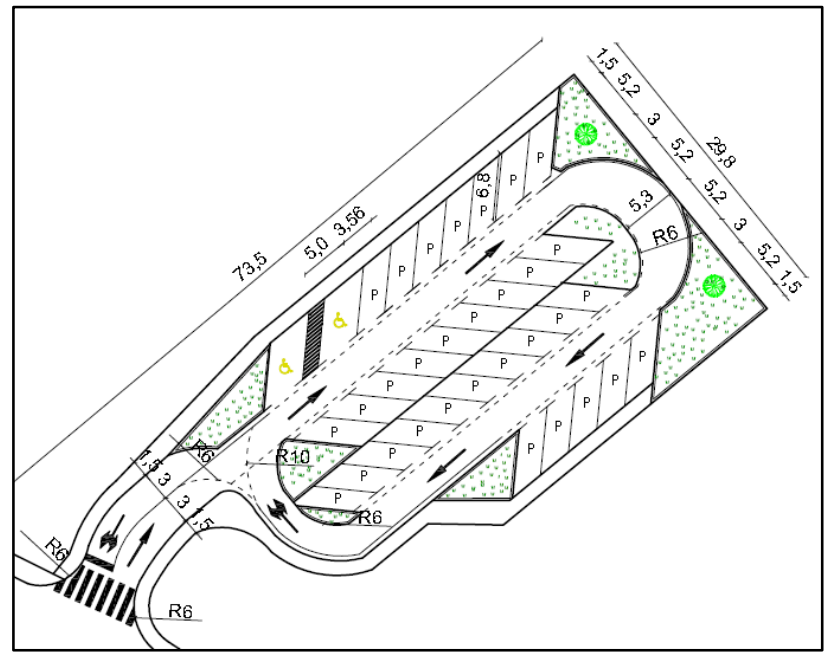

Slika 5. Parkiralište u Zagrebačkoj ulici [8] 
Uz navedeno, na svim mjestima koja su dostupna osobama koja se kreću u invalidskim kolicima osigurana su rezervirana parkirna mjesta (ukupno novih 5 PM uz postojeće te 2 na izvanuličnom parkiralištu).

\section{Zaključak}

Prijedlog unaprjeđenja prometnih uvjeta u gradu Otočcu na principima održive urbane mobilnosti izveden je na temelju analize postojećeg prometnog sustava i načina odvijanja svih vidova prometa u zoni obuhvata. Analizi su prethodila terenska istraživanja temeljem kojih je utvrđeno postojeće stanje čitavog područja obuhvata. Nije provedena analiza prometne sigurnosti koju bi svakako bilo dobro uključiti pri izradi ove vrste planova.

Iako dostupni podaci i priroda rada na kojem se temelji ovaj članak ne omogućavaju izradu cjelovitog plana održive mobilnosti, u radu su definirani ciljevi izrade plana kao i mjerljivi pokazatelji plana. Nastojalo se da rješenja budu izvediva uz manje investicije te se ponuđena rješenja temelje uglavnom na prenamjeni postojećih površina i raskrižja unutar postojećih gabarita. Kao novi objekt predlaže se izvanulično parkiralište koje ne predstavlja veliku investiciju.

Analiza unaprijed definiranih ciljeva i pokazatelja:

\begin{tabular}{|l|l|l|l|}
\hline Cilj & $\begin{array}{l}\text { Način mjerenja } \\
\text { postignutog cilja }\end{array}$ & $\begin{array}{l}\text { POSTOJEĆE } \\
\text { STANJE }\end{array}$ & PRIJEDLOG \\
\hline $\begin{array}{l}\text { Unaprjeđenje uvjeta za } \\
\text { biciklistički promet }\end{array}$ & $\begin{array}{l}\text { Duljina biciklističkih } \\
\text { putova odvojenih od } \\
\text { motornog prometa }\end{array}$ & $0 \mathrm{~m}$ & $950 \mathrm{~m}$ \\
\hline $\begin{array}{l}\text { Unaprjeđenje } \\
\text { pješačkog prometa }\end{array}$ & $\begin{array}{l}\text { Duljina novih ili } \\
\text { proširenih pješačkih } \\
\text { putova }\end{array}$ & - & $\begin{array}{l}\text { novih 110 } \\
\mathrm{m}\end{array}$ \\
\hline $\begin{array}{l}\text { Uklanjanje dužuličnih } \\
\text { parkirnih mjesta } \\
\text { u Ulici Kralja Zvonimira }\end{array}$ & $\begin{array}{l}\text { Broj dužuličnih } \\
\text { parkirnih mjesta }\end{array}$ & 242 PM & 210 PM \\
\hline $\begin{array}{l}\text { Osiguravanje kretanja } \\
\text { svim kategorijama } \\
\text { stanovništva }\end{array}$ & $\begin{array}{l}\text { Broj pješačkih prijelaza } \\
\text { prilagođenih kretanju } \\
\text { osoba slabije } \\
\text { pokretljivosti }\end{array}$ & 24 & 31 \\
\hline
\end{tabular}

Uz navedeno, treba napomenuti da je za jedno od raskrižja u zoni predložena rekonstrukcija u kružno raskrižje što bi doprinijelo sigurnosti odvijanja prometa, kako zbog manjeg broja potencijalnih kolizionih točaka, tako i zbog dokazanog efekta kružnih raskrižja na smanjenje brzine u zonama raskrižja [11]. 
Navedene mjere mogu se procijeniti kao pozitivan doprinos održivoj mobilnosti jer su osigurani uvjeti za biciklistički promet u zoni u kojoj postoji koncentracija sadržaja (škole, sportski objekti i sl.) te bi se istima mogla koristiti djeca i mladi, što doprinosi razvijanju njihovih zdravih navika. Unaprjeđeni su i uvjeti za pješačenje. Dio parkirnih mjesta iz Ulice Kralja Zvonimira je uklonjen, prvenstveno radi formiranja autobusnih ugibališta, a dijelom i zbog osiguravanja preglednosti na jednom od raskrižja (raskrižje 2). Autobusnim ugibalištima se osiguravaju preduvjeti za organizaciju javnog prijevoza u Otočcu, što bi sigurno povoljno utjecalo na život stanovnika okolnih naselja. Otočcu gravitiraju 22 naselja sa ukupno oko 5500 stanovnika. Povećanjem broja PM za invalidne osobe, kao i uređenjem svih pješačkih prijelaza, omogućava se lakše kretanje i ovoj skupini stanovništva. Uz navedene infrastrukturne mjere neophodno bi bilo uključivanje građana u razradu i promoviranje ponuđenih rješenja kako bi i korisnici, stanovnici Grada Otočca i okolnih naselja, lakše prepoznali dobrobiti prometnog sustava unaprijeđenog na načelima održive mobilnosti.

Zahvala. Prikazani rezultati proizašli su iz potpore znanstvenim istraživanjima „Održivo projektiranje kolničkih konstrukcija u urbanom području“, koju financira Sveučilište u Rijeci.

\section{Literatura}

[1] Tumlin, J. (2012.). Sustainable Transportation Planning, „John Wiley and Sons“, Hoboken, New Jersey

[2] Sustainable Urban Mobility Plan. http://www.mobilityplans.eu/docs/file/SUMP Brochure HR web.pdf (8.1.2018.)

[3] Planovi održive urbane mobilnosti. http://www.szz.hr/planovi-odrzive-urbane-mobilnosti\%E2\%80\%90sump (9.1.2018.)

[4] Projekt izrade plana održive mobilnosti Grada Siska. https://sisak.hr/wp-content/uploads/Projekt-izrade-plana-odr\%C5\%BEiveurbane-mobilnosti-Grada-Sisak-SUMP.pdf (9.1.2018.)

[5] Strategija razvoja grada Otočca 2014.-2018. https://otocac.hr/ (10.1.2018.)

[6] Grad Otočac - službena mrežna stranica http://www.otocac.hr (8.1.2018.)

[7] Službeni vjesnik Grada Otočca, broj 4/2014.

[8] Marković, D. (2017.), Unaprjeđenje prometnih uvjeta u Gradu Otočcu na načelima održive urbane mobilnosti-Diplomski rad, Građevinski fakultet Sveučilišta u Rijeci, Rijeka

[9] A Policy on Geometric Design of Highways and Streets, fourth edition, AASHTO, 2001. 
[10] Pravilnik o biciklističkoj infrastrukturi (NN 28/2016).

[11] Brown, M. (1995) TRL State of the Art Review-The Design of Roundabouts. London: HMSO, 1995. 